\title{
DIP-COATING SENYAWA KALSIUM FOSFAT DARI BATU KAPUR BUKIT TUI MELALUI METODE SOL-GEL
}

\author{
Novesar Jamarun, Lia Anggresani, Syukri Arief \\ Laboratorium Kimia Material, Jurusan Kimia, FMIPA Universitas Andalas \\ E-mail: novesar62@yahoo.com
}

\begin{abstract}
Preparation of Dip-Coating Calcium Phosphate via sol-gel method using natural limestone Bukit Tui as calcium precursors and diammonium hydrogen phosphate as phosphorus precursors with sol-gel process has been investigated. Ethanol was used as solvent and DEA (diethanolamine) was used stabilizing agent. The powder were prepared by calcinated the sol at $950{ }^{\circ} \mathrm{C}$. The products were characterized by Fourier Transform Infra Red, X-Ray Diffraction and Scanning Electron Microscopy. FTIR results showed that the vibration form was $\mathrm{PO}_{4}{ }^{3-}, \mathrm{P}_{2} \mathrm{O}_{7}{ }^{4-}, \mathrm{O}-\mathrm{H}$ and $\mathrm{CO}_{2}$. XRD patterns of powder with various $\mathrm{Ca} / \mathrm{P}$ mol ratio showed that the product of calcium phosphate was $\mathrm{Ca}_{2} \mathrm{P}_{2} \mathrm{O}_{7}$ and also found the hydroxyapatite $\mathrm{Ca}_{10}\left(\mathrm{PO}_{4}\right)_{6}(\mathrm{OH})_{2}$ in $\mathrm{Ca} / \mathrm{P}$ mol ratio 1,7. SEM images of powder calcium phosphate revealed that their morphology were spheric and homogen. The coating process was done at glass substrate with coating speed $20 \mathrm{~cm} / \mathrm{min}$ by calcinations at $400{ }^{\circ} \mathrm{C}$. XRD patterns of thin layer showed that the product was $\mathrm{Ca}_{2} \mathrm{P}_{2} \mathrm{O}_{7}$ and SEM images of thin layer revealed that their morphology were bulk.
\end{abstract}

Keywords: Natural limestone, calcium phosphate, hydroxyapatite, sol-gel, dip-coating

\section{DAFTAR PUSTAKA}

1. R. M. Vallet and C. J. M. Gonzalez, Calcium phosphates as substitution of bone tissues, Prog. Solid St. Chem., 32: 131, (2002).

2. C. B. Carter and M. G. Norton, Ceramic materials, science and engineering, Springer Science Business Media, LLC, New York, 2007, 644-645.

3. C. Liang, Z. Li, D. Yang, Y. Li, Z. Yang, and W. W. Lu, Synthesis of calsium phosphate/calsium sulphate powder, $J$. Materials Chemistry and Physics., 88: 285-289, (2004).

4. N. Jamarun, Rahmadanis, dan S. Arief, Pengaruh temperatur karbonasi pada pembentukan precipitated calcium carbonate (PCC), Jurnal Kimia Andalas., 11(1), (2005).

5. M. Kottaisamy, R. Jagannathan, $P$. Jeyagopal, R. P. Rao, dan R. L. Narayanan, $\mathrm{Eu}^{2+}$ luminescence in
$\mathrm{M}_{5}\left(\mathrm{PO}_{4}\right)_{3} \mathrm{X}$ apatites, where $\mathrm{M}$ is $\mathrm{Ca}^{2+}, \mathrm{Sr}^{2+}$ and $\mathrm{Ba}^{2+}$, and $\mathrm{X}$ is $\mathrm{F}^{-}, \mathrm{Cl}^{-}, \mathrm{Br}^{-}$and $\mathrm{OH}^{-}, J$. Phys. D., 27: 2210 - 2215, (1994).

6. M. Hassibi, Factors affecting quality of $\mathrm{CaO}, \quad 3^{\text {rd }}$ International Sorbalyt Symposium, New Orleans, USA, 1993.

7. N. Jamarun, Harmileni, dan S. Arief, Sintesis senyawa apatite dengan menggunakan batu kapur sebagai sumber kalsium. Proseding Semirata PTN Barat., 1: 770-777, (2010).

8. C. H. Souza, P. M. Marivalda, andM. H. Sander, Characterization of calsium phosphate coating and zinc incorporated on the porous alumina scaffolds, Materials Research., 10(1): 27-29, (2007).

9. E. Tkalcec, M. Sauer, R. Nonninger, and H. Schmidt, Sol-gel derived hydroxy-apatite powders and coating, Journal of Materials Science., 5253-5263, (2001).

10. L. D. Mo, T. Troczynski, and T. Wenjea, Water-based sol-gel synthesis of hydroxyapatite : process development, Biomaterials., 22: 1721-1730, (2001). 
